\title{
The degradation of guar gum by a faecal incubation system
}

\author{
By J. TOMLIN', N. W. READ ${ }^{1 *}$, C. A. EDWARDS 1 AND B. I. DUERDEN ${ }^{2}$ \\ ${ }^{1}$ Clinical Research Unit and ${ }^{2}$ Department of Medical Microbiology, \\ Royal Hallamshire Hospital, Sheffield S10 2JF
}

(Received 8 July 1985 - Accepted 29 November 1985)

\begin{abstract}
1. Homogenized and diluted faeces $(50 \mathrm{~g} / 1)$ from one human source were incubated with the complex plant polysaccharide, guar gum, to investigate the degradation of viscous polysaccharides by intestinal bacteria.

2. Incubation of the faecal homogenate with guar gum produced a rapid decrease in viscosity and in $\mathrm{pH}$, accompanied by the release of hydrogen.

3. No changes in viscosity or $\mathrm{pH}$ were observed and there was no production of $\mathrm{H}_{2}$ gas when guar gum was incubated with autoclaved faecal homogenate $\left(20 \mathrm{~min}, 1.03 \times 10^{5} \mathrm{~Pa}\right)$.

4. A bacteria-free filtrate of faeces was prepared by centrifuging the faecal homogenate $(2400 \mathrm{~g}$ for $100 \mathrm{~min})$ followed by filtration through a Seitz filter and then a millipore filter (size $0.45 \mu \mathrm{m}$ ). Incubating this with guar gum produced a slow decrease in viscosity, but no significant change in $\mathrm{pH}$ and no generation of $\mathrm{H}_{2}$.

5. Our results show that guar gum can be fermented by human colonic bacteria and suggest the possibility of predigestion by extracellular free enzymes.
\end{abstract}

Storage polysaccharides, such as guar gum, pectin and gum tragacanth are used clinically to treat diabetes mellitus, obesity and dumping syndrome (Jenkins et al. 1977; Leeds et al. 1981 ; Krotkiewski, 1984). They are not broken down by normal human digestive enzymes and form viscous gels in the stomach and small intestine which delay the absorption of glucose and other nutrients from the small intestine by several mechanisms (Holt et al. 1979; Morgan et al. 1979; Johnson \& Gee, 1980; Blackburn et al. 1984).

When they reach the large intestine, viscous polysaccharides may be broken down by the rich bacterial flora. The extent of colonic degradation of many polysaccharides is unknown. Some polysaccharides may not be broken down at all, others may be partially degraded leading to a decrease in viscosity, and others may be completely fermented to volatile fatty acids (VFA), and gases such as hydrogen and carbon dioxide.

Bacterial fermentation of viscous polysaccharides has several clinical implications: gas production may result in distension and flatulence (Jenkins et al. 1980); the reduction in $\mathrm{pH}$ may alter various aspects of colonic metabolism, for example the deconjugation of bile acids (Macdonald et al. 1978); and the loss of the water-holding properties of the viscous gel may decrease its potential effect on stool bulk and bowel function, although this action may be offset by the increased microbial mass stimulated by the additional carbohydrate source (Stephen \& Cummings, 1980).

Studies of the degradation of viscous polysaccharides by colonic bacteria in vitro may help to explain the clinical actions of polysaccharides that are currently used in therapy, and to predict the possible clinical application of new polysaccharide substances. This study has used a faecal incubation system to investigate how a mixed population of faecal bacteria digests guar gum. It is assumed that the bacteria in fresh faeces are the same as the bacteria of the colon and rectum. Studies on sudden death victims have shown that the composition of the lumenal flora remains relatively constant from ascending colon to rectum (Moore et al. 1978) and that the flora of the mucosa is as complex as that in faeces (Croucher et al. 1983). 
Table 1. Composition of the medium

\begin{tabular}{|c|c|c|}
\hline Component & Concentration & Sterilization procedure \\
\hline $\begin{array}{l}\text { Sodium chloride } \\
\text { Sodium bicarbonate } \\
\text { Potassium chloride } \\
\text { Tryptone* }\end{array}$ & $\begin{array}{l}60 \mathrm{mM} \\
40 \mathrm{mM} \\
10 \mathrm{mM} \\
10 \mathrm{~g} / 1\end{array}$ & $\begin{array}{c}\text { Dissolved in distilled } \\
\text { water, then autoclaved } \\
\text { at } 1.03 \times 10^{5} \mathrm{~Pa} \text { for } \\
20 \mathrm{~min}\end{array}$ \\
\hline Hemin $\dagger$ & $5 \times 10^{-5} \mathrm{~g} / \mathrm{l}$ & $\begin{array}{l}\text { Dissolved in sodium } \\
\text { hydroxide solution } \\
(100 \mathrm{~g} / 1) \text { then filter } \\
\text { sterilized and added } \\
\text { to the above }\end{array}$ \\
\hline
\end{tabular}

* Oxoid Ltd, Basingstoke.

$\dagger$ BDH Chemicals Ltd, Poole, Dorset.

\section{METHODS}

Guar gum $(5 \mathrm{~g} / 1)$ was incubated with a faecal homogenate that was untreated or had been filtered to remove bacteria and leave extracellular enzymes or had been autoclaved to destroy the bacteria and the enzymes. Changes in viscosity and $\mathrm{pH}$ during the incubation were measured, and gases produced were collected for analysis.

\section{Experimental procedures}

Powdered guar gum (Hercules Powder Co., Erith, Kent) was made up as a solution $(10 \mathrm{~g} / \mathrm{l})$ in sterile medium (Table 1). To model conditions at the ileo-caecal transition the electrolyte composition of the medium was based on ileostomy effluent and the $\mathrm{pH}$ used was at the upper end of the $\mathrm{pH}$ range seen in the terminal ileum by Bown et al. (1974).

Fresh human faeces were collected from a healthy donor, who was taking a normal Western diet and had not taken antibiotics for 6 months. A $10 \mathrm{~g}$ sample was homogenized in $200 \mathrm{ml}$ of sterile medium $(50 \mathrm{~g} / \mathrm{l})$ under anaerobic conditions created by vigorous bubbling with nitrogen- $\mathrm{CO}_{2}(0 \cdot 95: 0 \cdot 05, \mathrm{v} / \mathrm{v})$.

The faecal homogenate was then divided into three: $(a)$ a portion was left untreated and so contained bacteria and free enzymes in the faecal water; $(b)$ a portion was centrifuged at $2400 \mathrm{~g}$ for $100 \mathrm{~min}$, Seitz filtered and then passed through a millipore filter (pore size $0.45 \mu \mathrm{m}$ ) at room temperature, to exclude bacteria but leave the free enzymes; $(c)$ a portion was autoclaved at $1.03 \times 10^{5} \mathrm{~Pa}$ (equivalent to $120^{\circ}$ ) for $20 \mathrm{~min}$ so that bacteria were killed and enzymes denatured. Inoculations were made into sterile $30 \mathrm{~g}$ universal bottles in an anaerobic cabinet (Don Whitley, Baildon, W. Yorks) that contained $\mathrm{N}_{2}-\mathrm{CO}_{2}-\mathrm{H}_{2}$ $(0 \cdot 8: 0 \cdot 1: 0 \cdot 1, \mathrm{v} / \mathrm{v})$.

Each set of experiments consisted of seven incubations; they comprised a test incubation for each of the three faecal preparations (untreated, filtered and autoclaved) with guar gum, a control incubation for each of the three faecal preparations in which guar gum was replaced by sterile medium, and one control incubation in which sterile medium replaced the faecal preparation. These mixtures were made up in duplicate (one set of seven bottles was analysed within 40 min to give the initial readings and the other set was incubated at $37^{\circ}$ for $21 \mathrm{~h}$ and then analysed to give the final readings).

\section{Measurements}

The viscosity was measured with an Otswald viscometer (Mark, 1945), capillary bore $2 \mathrm{~mm}$, 
Table 2. Changes in viscosity of the cultures on incubation at $37^{\circ}$ for $21 \mathrm{~h}$

(Mean values with their standard errors)

\begin{tabular}{|c|c|c|c|c|c|c|}
\hline \multirow[b]{3}{*}{ Components } & & \multicolumn{4}{|c|}{ Viscosity (mPas) } & \multirow{3}{*}{$\begin{array}{c}\text { Statistical } \\
\text { signifi- } \\
\text { cance of } \\
\text { difference: } \\
P<\end{array}$} \\
\hline & & \multicolumn{2}{|c|}{ Initial } & \multicolumn{2}{|c|}{ Final } & \\
\hline & & Mean & $\mathrm{SE}$ & Mean & $\mathrm{SE}$ & \\
\hline Guar gum alone & Control & $173 \cdot 6$ & $12 \cdot 4$ & $150-0$ & $13 \cdot 9$ & NS \\
\hline Untreated faeces & Control & 1.9 & 0.0 & $2 \cdot 0$ & 0.0 & NS \\
\hline Untreated faeces & With guar gum & $43 \cdot 3$ & $8 \cdot 0$ & $2 \cdot 2$ & 0.0 & $0 \cdot 001$ \\
\hline Filtered faeces & With guar gum & 174.4 & $35 \cdot 2$ & $13 \cdot 3$ & $3 \cdot 2$ & 0.001 \\
\hline Autoclaved faeces & With guar gum & $216 \cdot 2$ & $17 \cdot 8$ & $191 \cdot 0$ & 110 & NS \\
\hline
\end{tabular}

NS, not significant.

calibrated with olive oil at the same temperature as the sample to be tested (room temperature). Viscosity was calculated from the formula:

$$
V_{\mathrm{s}}=\frac{t_{\mathrm{s}} \times d_{\mathrm{s}} \times V_{o}}{t_{o} \times d_{\mathrm{o}}}
$$

where $V$ is viscosity, $t$ is time, $d$ is density, $\mathrm{o}$ is olive oil and $\mathrm{s}$ is sample.

This method is not valid for non-Newtonian fluids, but since guar gum is thought to act as a Newtonian fluid up to a concentration of $5 \mathrm{~g} / 1$ (Goldstein et al. 1973), the maximum concentration found in any of the cultures, the results are adequate for comparisons within the study.

The $\mathrm{pH}$ was measured before and after incubation using a $\mathrm{pH}$ electrode connected to a pH meter (Model 10; Corning Eel, Medfield, MA, USA).

Gases produced during the incubation were collected in a greased glass syringe. This was connected to the small gas space above the incubation mixture via a three-way tap and a needle pushed through a small hole in the metal cap and through the rubber seal beneath. The syringe contents were analysed for $\mathrm{H}_{2}$ concentration using a breath $\mathrm{H}_{2}$ monitor (Hansatech, King's Lynn) calibrated from 0 to $96 \mu \mathrm{l} / \mathrm{l}$ with air and a standard gas mixture (GMI, Renfrew, Scotland).

\section{Statistical analysis}

Results were analysed statistically by Student's paired $t$ test.

\section{RESULTS}

Untreated faeces

A very rapid decrease in viscosity to about $25 \%$ of the value for the guar gum control $(P<0.01)$ was observed within 40 min of mixing guar gum with the untreated faeces (Table 2). Incubation for $21 \mathrm{~h}$ caused a further reduction in viscosity $(P<0.01)$ to the same level as that of the faecal suspension without guar gum and significantly lower than the corresponding value for the guar gum control $(P<0 \cdot 01)$. This reduction in viscosity was accompanied by the production of $\mathrm{H}_{2}$ gas and a fall in $\mathrm{pH}$ to values lower than the initial value and either control $(P<0 \cdot 01)$ (Table 3$)$.

Control cultures containing untreated faeces but no guar gum had a low viscosity that 
Table 3. Changes in pH of the cultures and hydrogen concentration produced on incubation at $37^{\circ}$ for $21 \mathrm{~h}$

(Mean values with their standard errors)

\begin{tabular}{|c|c|c|c|c|c|c|c|c|}
\hline \multirow[b]{3}{*}{ Components } & & \multicolumn{4}{|c|}{$\mathrm{pH}$} & \multirow{3}{*}{$\begin{array}{c}\text { Statistical } \\
\text { signif- } \\
\text { cance of } \\
\text { difference: } \\
P<\end{array}$} & \multirow{2}{*}{\multicolumn{2}{|c|}{$\begin{array}{c}\text { Mean } \mathrm{H}_{2} \\
\text { concentration } \\
(\mathrm{ml} / \mathrm{l})\end{array}$}} \\
\hline & & \multicolumn{2}{|c|}{ Initial } & \multicolumn{2}{|c|}{ Final } & & & \\
\hline & & Mean & $\mathrm{SE}$ & Mean & $\mathrm{SE}$ & & Mean & SE \\
\hline Guar gum alone & Control & 8.60 & $0 \cdot 10$ & $8 \cdot 29$ & 0.08 & 0.05 & 0 & \\
\hline Untreated faeces & Control & $8 \cdot 12$ & 0.26 & 6.91 & $0 \cdot 24$ & 0.001 & $26 \cdot 8$ & $18 \cdot 8$ \\
\hline Untreated faeces & With guar gum & $8 \cdot 14$ & $0 \cdot 21$ & $6 \cdot 18$ & $0 \cdot 10$ & 0.001 & 63.8 & $31 \cdot 7$ \\
\hline Filtered faeces & With guar gum & $8 \cdot 39$ & 0.21 & 8.00 & $0 \cdot 10$ & NS & 0 & \\
\hline Autoclaved faeces & With guar gum & 8.75 & $0 \cdot 30$ & 8.60 & $0 \cdot 30$ & NS & 0 & \\
\hline
\end{tabular}

NS, not significant.

did not change during incubation $(P>0.05)$ (Table 2$)$. There was, however, a reduction in the $\mathrm{pH}$ of the cultures and some $\mathrm{H}_{2}$ was generated, although the changes were much less than those observed when guar gum was present $(P<0.01)$ (Table 3$)$.

No significant $\mathrm{pH}$ reduction or $\mathrm{H}_{2}$ production occurred in the control mixtures that did not contain the untreated faeces (Table 3 ).

\section{Filtered faeces}

When bacteria were excluded from the faecal homogenate by filtration, the initial viscosity value of the guar gum with filtered faeces was not significantly different from that of the guar gum control (Table 2). The viscosity of the incubated mixture, however, was reduced to about $9 \%$ of that of the guar gum control $(P<0 \cdot 01)$; significantly lower than its original value $(P<0.01)$ (Table 2$)$ but still higher than the viscosity of the guar gum incubated with untreated faeces $(P<0.01)$.

The reduction in viscosity observed on incubating guar gum with filtered faeces was not accompanied by a significant fall in $\mathrm{pH}$ or the production of $\mathrm{H}_{2}$ (Table 3).

\section{Autoclaved faeces}

When the faecal homogenate was heat-sterilized to destroy both bacteria and enzymes, the results were little different from control measurements. The initial viscosity of the mixture was in fact slightly higher than that of the guar gum control $(P<0.05)$ (Table 2). This is probably due to a loss of liquid from the faeces during sterilization, making the actual concentration of guar gum in the mixture slightly greater than $5 \mathrm{~g} / \mathrm{l}$. The final viscosity value, however, was not significantly different either from its corresponding initial value or from the final value of the guar gum control.

Incubation of guar gum with autoclaved faeces did not cause the $\mathrm{pH}$ to fall $(P>0.05)$ and did not generate any $\mathrm{H}_{2}$ gas (Table 3 ).

\section{DISCUSSION}

Guar gum was rapidly degraded by a homogenate of faeces; the viscosity was reduced by $75 \%$ within $40 \mathrm{~min}$ and the $\mathrm{pH}$ also fell significantly. After incubation for $21 \mathrm{~h}$, the viscous properties of the mixture were no different from those of the homogenized faeces control, 
the $\mathrm{pH}$ had fallen significantly by an average of $1.7 \mathrm{pH}$ units and a high concentration of $\mathrm{H}_{2}$ gas had been produced. These changes were almost certainly caused by bacterial action, since they did not occur during incubation of guar gum with autoclaved faeces. The smaller reduction in $\mathrm{pH}$ and release of $\mathrm{H}_{2}$ observed when the untreated faecal preparation was incubated without guar gum can probably be explained by bacterial fermentation of substrates already present in the faeces, such as mucoproteins (Hoskins \& Boulding, 1981) and unabsorbed polysaccharides from foodstuffs. Tryptone present in the medium may also be digested, but experiments with cultures of single species of bacteria suggest that whilst $\mathrm{H}_{2}$ can be produced in this way, changes in $\mathrm{pH}$ (presumably reflecting production of VFA) cannot (J. Tomlin, C. A. Edwards, B. I. Duerden and N. W. Read, unpublished results).

These experiments have confirmed that guar gum can be fermented by faecal bacteria, resulting in a total abolition of its viscous properties. This result could explain why the contents of the large intestine of rats fed on guar gum are no more viscous than those of controls (Blackburn \& Johnson, 1981) and why guar gum has a variable effect on faecal bulking in man (Cummings et al. 1978) but produces a large amount of gas (Jenkins $e t$ al. 1980).

The incubation of guar gum with a bacteria-free filtrate of faeces produced a significant reduction in viscosity but, in contrast to the findings with untreated faeces, there was no change in $\mathrm{pH}$ and no generation of $\mathrm{H}_{2}$. This observation suggests that the presence of bacteria is necessary for the $\mathrm{pH}$ reduction and release of $\mathrm{H}_{2}$ but that the viscosity reduction can be produced by extracellular enzymes in the filtrate. A reduction in viscosity caused by an interaction between polysaccharide and protein in the faecal filtrate seems unlikely because there is little or no interaction between proteins and non-ionic gums such as guar gum (Ganz, 1974) and any coacervation would tend to increase, rather than reduce, the observed viscosity. Production of extracellular enzymes in response to viscous polysaccharides does occur in isolated strains of colonic anaerobes (Salyers et al. 1978) and an extracellular enzyme that reduces the viscosity of guar gum has been observed in cultures of Bacteroides ovatus, although there was no simultaneous monitoring of $\mathrm{pFi}^{-}$or gas production in that study (Balascio et al. 1981). The enzymes in the filtrate actually could be secreted by the bacteria or they could be released by cell lysis either during slow passage through the colon or during preparation of the bacteria-free filtrate. The viscous properties of guar gum in solution may make it difficult for bacteria to gain access to the polysaccharide; it is possible that predigestion by extracellular enzymes could render the gum less viscous and so more readily accessible to bacteria. It is likely that guar gum is broken down by a number of enzymic stages before fermentation occurs; extracellular enzymes may reduce the viscosity and generate high-molecular-mass products, bacteriaassociated mannanases clip the backbone at every 3 rd to 7 th unit and, finally, bacterial $\alpha$-galactosidase ( $E C$ 3.2.1.22) and $\beta$-mannosidase $(E C$ 3.2.1.25) break apart the remaining sugar molecules and allow fermentation to proceed (Emi et al. 1972; Prizont $e t$ al. 1976; Gherhardini \& Salyers, 1982).

Salyers et al. $(1977 a, b)$ found that a surprisingly small proportion (twenty-nine of 286 strains) of anaerobic colonic bacteria tested could ferment guar gum in isolation. It is possible that these are the strains that can produce extracellular enzymes, and that many other strains could have fermented the guar gum if the preliminary digestion stage had been performed.

Production of extracellular enzymes is often induced by the presence of their substrate (Salyers et al. 1978), suggesting that the bacterial species in the faecal samples used in the present study had been exposed to the linkages present in guar gum in situ. This is possible since guar gum is a common food additive in concentrations up to $20 \mathrm{~g} / \mathrm{kg}$ (Bowes \& Church, 1975), and polysaccharides with $\beta-1 \rightarrow 4$ manno-pyranosyl and $\alpha-1 \rightarrow 6$ 


\section{J. Tomlin, N. W. Read, C. A. Edwards and B. I. Duerden}

galacto-pyranosyl linkages are present in many beans (especially soya) and peas (Royal College of Physicians of London, 1980).

This work was supported by a CASE award from the SERC.

\section{REFERENCES}

Balascio, J. R., Palmer, J. K. \& Salyers, A. A. (1981). Journal of Food Biochernistry 5, $271-282$.

Blackburn, N. A. \& Johnson, I. T. (1981). British Journal of Nutrition 46, 239-246.

Blackburn, N. A., Redfern, J. S., Jarjis, H., Holgate, A. M., Hanning, I., Scarpello, J. H. B., Johnson, I. T. \& Read, N. W. (1984). Clinical Science 66, 329-336.

Bowes, A. P. \& Church, C. F. (editors) (1975). In Food Values of Portions Commonly Used, p. 166, 12th ed. New York: J. B. Lippincott Co.

Bown, R. L., Gibson, J. A., Sladen, G. E., Hicks, B. \& Dawson, A. M. (1974). Gut 15, 999-1004.

Croucher, S. C., Houston, A. P., Bayliss, C. A. \& Turner, R. J. (1983). Applied and Environmental Microbiology 45, 1025-1033.

Cummings, J. H., Branch, W. J., Jenkins, D. J., Southgate, D. A., Houston, H. \& James, W. P. (1978). Lancet i, $5-8$.

Emi, S., Fukumoto, J. \& Yamamoto, T. (1972). Agricultural and Biological Chemistry 36, 991-1001.

Ganz, A. J. (1974). Food Engineering 46, 67-69.

Gherhardini, F. \& Salyers, A. A. (1982). Abstracts of the Annual Meeting of the American Society of Microbiology p. $147, \mathrm{~K} 64$.

Goldstein, A. M., Alter, E. N. \& Seaman, J. K. (1973). In Industrial Gums, pp. 303-321, 2nd ed. [R. L. Whistler and J. N. BeMiller, editors]. New York: Academic Press.

Holt, S., Heading, R. C., Carter, D. C., Prescott, L. F. \& Tothill, P. (1979). Lancet i, 636-639.

Hoskins, L. C. \& Boulding, E. T. (1981). Journal of Clinical Investigation 67, 163-172.

Jenkins, D. J. A., Reynolds, D., Slavin, B., Leeds, A. R., Jenkins, A. L. \& Jepson, E. M. (1980). American Journal of Clinical Nutrition 33, 575-581.

Jenkins, D. J. A., Wolever, T. M. S., Hockaday, T. D. R., Leeds, A. R., Howarth, R., Bacon, S., Apling. E. C. \& Dilawari, J. B. (1977). Lancet ii, 779-780.

Johnson, I. T. \& Gee, J. M. (1980). Proceedings of the Nutrition Society 39, 52 A.

Krotkiewski, M. (1984). British Journal of Nutrition 52, 97-105.

Leeds, A. R., Ralphs, D. N. L., Ebied, F., Metz, G. \& Dilawari, J. B. (1981). Lancet i, 1075-1078.

Macdonald, I. A., Singh, G., Mahony, D. E. \& Meier, C. E. (1978). Steroids 32, 245-256.

Mark, H. (1945). In Physical Methods of Organic Chemistry, vol. 1, pp. 135-147 (A. Weissburger, editor). New York: Interscience.

Moore, W. E. C., Cato, E. P. \& Holdeman, L. V. (1978). American Journal of Clinical Nutrition 31, S33-S42.

Morgan, L. M., Goulder, T. J., Tsiolakis, D., Marks, V. \& Alberti, K. G. (1979). Diabetologia 17, 85-89.

Prizont, R., Konigsberg, N. \& Aminoff, D. (1976). Gastroenterology 70, A70/928.

Royal College of Physicians of London (1980). Medical Aspects of Dietary Fibre, 1st ed., pp. 12-25. Tonbridge, Kent: Pitman Medical Ltd.

Salyers, A. A., Palmer, J. K. \& Wilkins, T. D. (1978). American Journal of Clinical Nutrition 31, S128-S130.

Salyers, A. A. Vercellotti, J. R., West, S. E. H. \& Wilkins, T. D. (1977a). Applied and Environmental Microbiology 33, 319-322.

Salyers, A. A., West, S. E. H., Vercellotti, J. R. \& Wilkins, T. D. (1977b). Applied and Environmental Microbiology 34, 529-533.

Stephen, A. M. \& Cummings, J. H. (1980). Journal of Medical Microbiology 13, 45-56. 